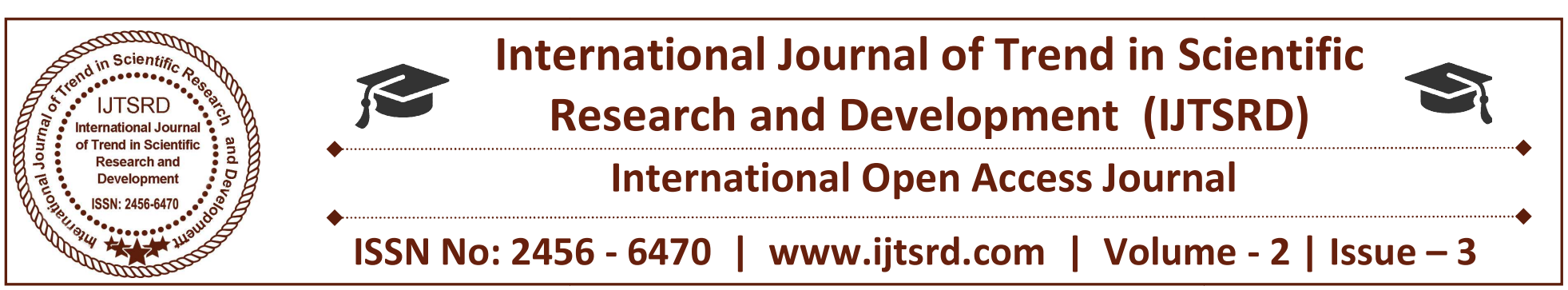

\title{
Isolation and Optimization of Protease Producing Bacteria from Marine Sediment
}

\author{
P. Maheswari, S. Mahendran, A. Kamilabanu \\ Post Graduate and Research Department of Microbiology, \\ Ayya Nadar Janaki Ammal College (Autonomous), Sivakasi, Tamil Nadu, India
}

\begin{abstract}
In the present study investigation protease producing potent bacterial strain was isolated from the Marine sediment soil. Based on the morphology, biochemical and $16 \mathrm{~S}$ rRNA sequencing, it was identified as Oceanobacillus iheyensis. The optimisation of protease production in submerged fermentation at various parameters like $\mathrm{pH}$, temperature, carbon, nitrogen, metal ions, sodium chloride, surfactants, inoculums concentration, incubation time, static, shaking, aminoacids and buffers were tested. The isolated crude protease enzyme was partially purified by using Sephadex-A50 column chromatography.
\end{abstract}

Keywords: Ocenobacillus iheyensis, Protease, 165 rRNA sequencing, optimization, Sephadex-A50 and surfactant

\section{INTRODUCTION}

Enzymes are biological catalysts; they are highly specialized catalytic proteins with extra ordinary catalytic power and also have remarkable specificity. They are extracellular essential for all forms of life by catalyzing the chemical reactions in the cells (Anushu et.al, 2007). Proteases are necessary for life of living organisms being found in wide diversity, which performs both degradative and synthetic functions (Ferid abidi et al., 2008). Proteases have been found in almost every micro-source such as bacteria, fungi and yeast (Phetcharat and Duangpaeng, 2012). Nowadays, with the increasing number of researches in bacteria isolated from fermented food, the proteolytic enzyme produced by these kinds of bacteria also comes to the researchers' sight. The proteolytic enzymes can be found almost from any sources such as bacteria and fungi, on the other hand,

it was found in plant and animal (Costa et al., 2010). The caseinase was studied in several different kinds of fungi (Absidia cylindrospora, Aspergillus flavus, Aspergillus ochraceus, Aspergillus wentii, Penicillium canescens, Syncephalastrum sp.). Alkaline proteases are produced by a wide range of microorganisms including bacteria, molds and yeasts. In bacteria, this enzyme is produced mainly by many members belonging to genus Bacillus especially, B.licheniformis; B. horikoshii, B. sphaericus, Bacillus furmis, Bacillus alcalophilus and Bacillus subtilis (Ellaiah et al., 2002). Alkaliphiles are defined as organisms which exhibit optimum growth in an alkaline $\mathrm{pH}$ environment, particularly in excess of $\mathrm{pH}$ 8 , and generally in the range between $\mathrm{pH} 9$ and 10 . Alkaliphiles may also be found in environments having a $\mathrm{pH}$ as high as 12 . HPLC is a versatile, robust and widely used technique for the isolation of natural products. It is a chromatographic technique that can separate a mixture of compounds and is used in phytochemical and analytical chemistry to identify, quantify and purify the individual components of the mixture. (Martin and Guiochon, 2005). For several physiological processes the action of the proteolytic enzyme is essential, e.g. in digestion of food proteins, protein turnover, cell division, blood clotting cascade, signal transduction, processing of polypeptide hormones, apoptosis and also in the life cycle of disease - causing organisms including the replication of retrovirus (Delvin et al., 2002). They are widely used as detergent, in food, pharmaceutical and leather tanning industries (Kalpana Devi et al., 2008). Microbial proteases are increasingly used in treatment of various disorders namely cancer, inflammation, cardiovascular disorders, necrotic wounds etc. (Sabu 
et al., 2003). In the present study protease producing marine bacteria was identified and enzyme was purified by using HPLC.

\section{MATERIALS AND METHODS}

\section{Isolation and identification of proteolytic bacteria}

The soil sample was collected from Rameswaram, Mandabam beach area, Ramanathapuram (Dist), Tamilnadu, India. The soil sample was serially diluted. $0.1 \mathrm{ml}$ of the diluted sample was plated on zobell marine agar plates. The plates were incubated at $37^{\circ} \mathrm{C}$ for 24 hours. Casein agar medium was sterilized at $121^{\circ} \mathrm{C}$ for $15 \mathrm{mins}$ at $15 \mathrm{lbs}$ pressure. The isolates were streaked on the medium. The zone formed around the colonies due to the production of caseinase enzyme, which is used to hydrolyse the casein. Isolated bacterial colonies were identified by morphological, biochemical and molecular characters.

\section{Enzymatic hydrolysis of casein}

$0.5 \mathrm{ml}$ of casein solution was incubated with $0.5 \mathrm{ml}$ of enzyme solution at $37^{\circ} \mathrm{C}$. After $10 \mathrm{mins}$, the reaction was terminated by addition of $1 \mathrm{ml}$ of $10 \%$ trichloro acetic acid. The mixture was centrifuged at 10,000 rpm for 5mins. Supernatant was collected $5 \mathrm{ml}$ of $0.44 \mathrm{M}$ Sodium carbonate and $1 \mathrm{ml}$ of two fold diluted Folin's reagent were added. After 30 mins incubation, blue colour developed was read at $660 \mathrm{~nm}$ against a reagent blank prepared in the same manner without enzyme (Kunitz, 1947).

\section{Media optimization for protease production}

The crude protease enzyme obtained by cultivating the selected strains under the optimized conditions was investigated. The factors like $\mathrm{pH}$, temperature, carbon, nitrogen, metal ions, Nacl, surfactants, inoculum size, incubation time, amino acids, buffers, RPM, static and shaking condition (EI-Enshasy, 2008).

\section{PURIFICATION OF PROTEASE CARBINOL PRECIPITATION}

In the present study, 48 hours fermented medium was extracted and centrifuged at $10,000 \mathrm{rpm}$ for $10 \mathrm{mins}$. Carbinol was added to the crude extract with constant stirring between $50 \%$ and $70 \%$ of saturation. The samples were stored at $4^{\circ} \mathrm{C}$ for overnight. The supernatant was removed and the precipitate was dissolved in buffer Glycine $\mathrm{NaOH}$ and $\mathrm{pH} \quad 10$ Maruthaiah et al., (2014).

\section{High Performance of Liquid Chromatography (HPLC) analysis}

The crude extract of Oceanobacillus iheyensis KB7 was analyzed for protein component (enzyme) study through HPLC. The instrumentation was performed using waters 600 pump and waters 2487 dual detector set to $270 \mathrm{~nm}$. The separation was carried out with an isocratic elution program $\left(60 \% \mathrm{CH}_{3} \mathrm{CN}, 40 \% \mathrm{H}_{2} 0\right)$, waters Nova-Pack C18 column $(4 \mathrm{Km}, 3.9 \times 20 \mathrm{~mm})$ adapted to flow rate of $1 \mathrm{ml} / \mathrm{min}$. Acetonitrile $\left(\mathrm{CH}_{3} \mathrm{CN}\right)$ was HPLC grade from Merck (Darmstadt, Germany); Distilled water $\left(\mathrm{H}_{2} \mathrm{O}\right)$ was purified by a Milli-Q system (Millipore, m Bedford, MA,USA). The analyses were carried out at room temperature $\left(25^{\circ} \mathrm{C}\right)$ and with volume of $20 \mu \mathrm{l}$ and three injections. Peaks were identified by comparision of their retention times. The presence of enzyme components was analyzed through the instrument and they were plotted in the graphical format by appearing peaks.

\section{RESULTS}

\section{Identification of protease producing bacteria}

The selected strain was identified by various morphological, biochemical analysis and molecular Characterisation. The protease producing bacteria was identified as Oceanobacillus sp. by following the standard keys of Bergeys manual (Table 1). The phylogenetic analysis of the $16 \mathrm{~S}$ rRNA sequencing of the bacteria Oceanobacillus iheyensis has 94\% similarity with the nearest match in the genbank.

Table 1: Morphological and biochemical characteristics of Oceanobacillus sp.

\begin{tabular}{|l|c|}
\hline Cultural Characteristics & Observation \\
\hline Gram's staining & $\begin{array}{c}\text { Gram positive, } \\
\text { short rod. } \\
\text { Non-motile. }\end{array}$ \\
\hline Motility & - \\
\hline Biochemical characteristics & + \\
\hline Indole production test & + \\
\hline Methyl red test & - \\
\hline Voges-Proskauer test & - \\
\hline Citrate utilization test & + \\
\hline Oxidase & - \\
\hline Urease test & + \\
\hline TSI & \\
\hline Catalase & + \\
\hline Carbohydrate fermentation tests & - \\
\hline Glucose & \\
\hline Arabinose & \\
\hline
\end{tabular}


International Journal of Trend in Scientific Research and Development (IJTSRD) ISSN: 2456-6470

\begin{tabular}{|l|c|}
\hline Mannitol & + \\
\hline Maltose & - \\
\hline Lactose & + \\
\hline Galactose & + \\
\hline Starch hydrolysis & + \\
\hline Casein hydrolysis & + \\
\hline
\end{tabular}

\section{Screening of protease producing bacteria}

The isolated bacteria was screened for protease enzyme producing ability of casein agar which form a clear zone to hydrolysis of casein showed in fig. 1 .

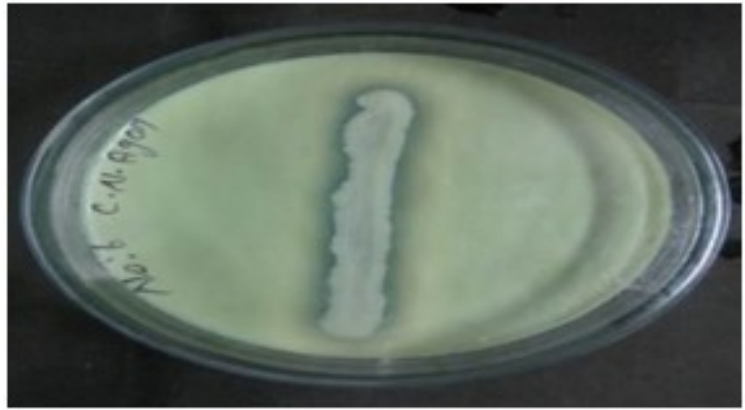

Fig. 1: Protease activity of Oceanobacillus iheyensis on casein agar plate

Optimization of cultural conditions for protease production

\section{Effect of pH on protease production}

Maximum protease production for Oceanobacillus iheyensis $K B 7$ was recorded at $\mathrm{pH} 8$ (total activity $1.455 \pm 0.003 \mathrm{IU} / \mathrm{ml}$ ). Minimum protease production for Oceanobacillus iheyensis $K B 7$ was recorded at $\mathrm{pH}$ $2.0(0.628 \pm 0.003 \mathrm{IU} / \mathrm{ml})$ (Fig. 3)

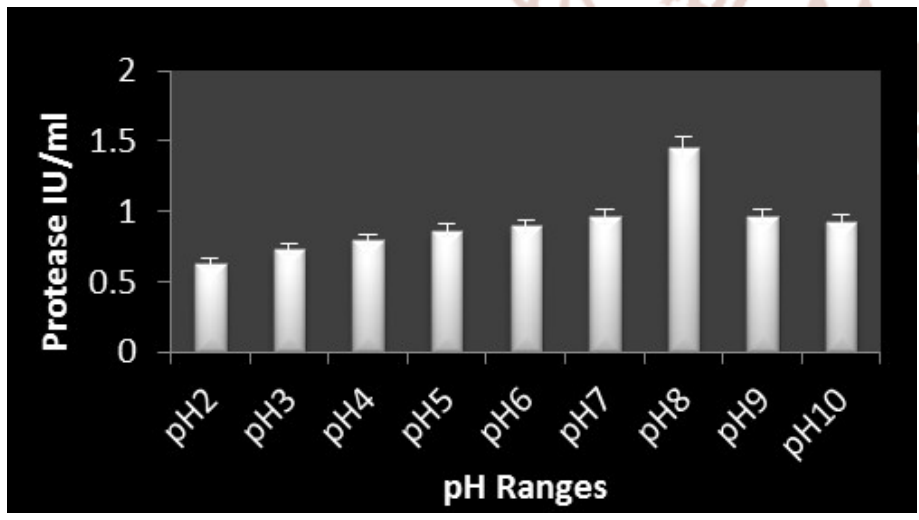

Fig. 3 Effect of pH on protease production

\section{Effect of temperature on protease production}

The protease production was assayed under various temperatures like $10,20,30,40$ and $50^{\circ} \mathrm{C}$ at $72 \mathrm{hrs}$ incubation. Maximum protease production for
Oceanobacillus iheyensis $K B 7$ was recorded at $40^{\circ} \mathrm{C}$ (total activity $1.325 \pm 0.003 \mathrm{IU} / \mathrm{ml}$ ). Minimum protease production for Oceanobacillus iheyensis KB7 was recorded at $10^{\circ} \mathrm{C}$ (total activity $0.362 \pm 0.114$ $\mathrm{IU} / \mathrm{ml}$ ) (fig. 4).

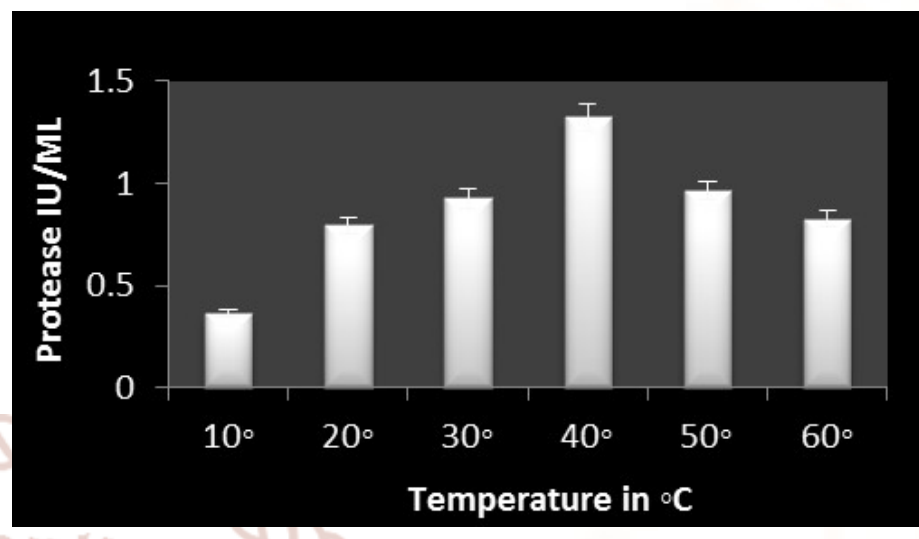

Fig. 4 Effect of temperature on protease production

\section{Effect of carbon sources on protease production}

Here the maximum protease production was recorded in lactose (total activity $1.163 \pm 0.003 \mathrm{IU} / \mathrm{ml}$ ). The minimum protease production was recorded in sucrose (total activity $0.596 \pm 0.002 \mathrm{IU} / \mathrm{ml}$ ) (fig. 5).

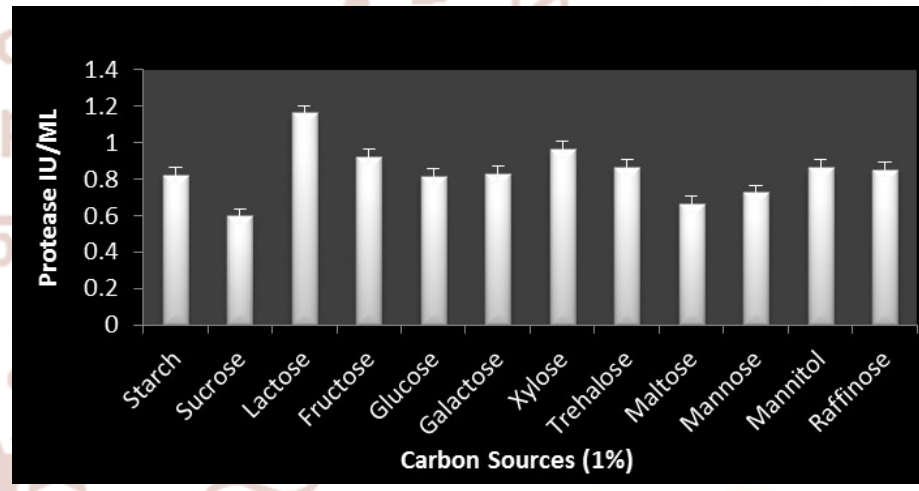

Fig. 5 Effect of carbon sources on protease production

\section{Effect of nitrogen sources on protease production}

After $72 \mathrm{hrs}$ of incubation period at $40^{\circ} \mathrm{C}$ showed maximum amount of enzyme production in peptone (total activity $0.895 \pm 0.002 \mathrm{IU} / \mathrm{ml}$ ) and the minimum amount of protease production in ammonium sulfate (total activity $0.366 \pm 0.002 \mathrm{IU} / \mathrm{ml}$ ) (fig. 6) was observed. 


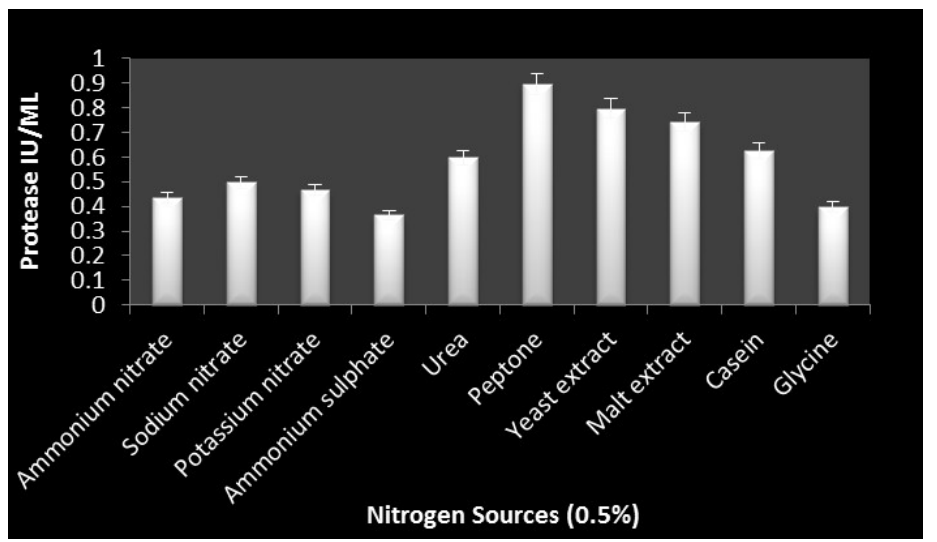

\section{Effect of metal ions on protease production}

Maximum amount of enzyme production in calcium chloride (total activity $0.864 \pm 0.003 \mathrm{U} / \mathrm{ml}$ ) and minimum amount of protease production in mercuric oxide (total activity $0.524 \pm 0.003 \mathrm{IU} / \mathrm{ml}$ ) (fig. 7) was observed.

Fig. 6 Effect of nitrogen sources on protease production

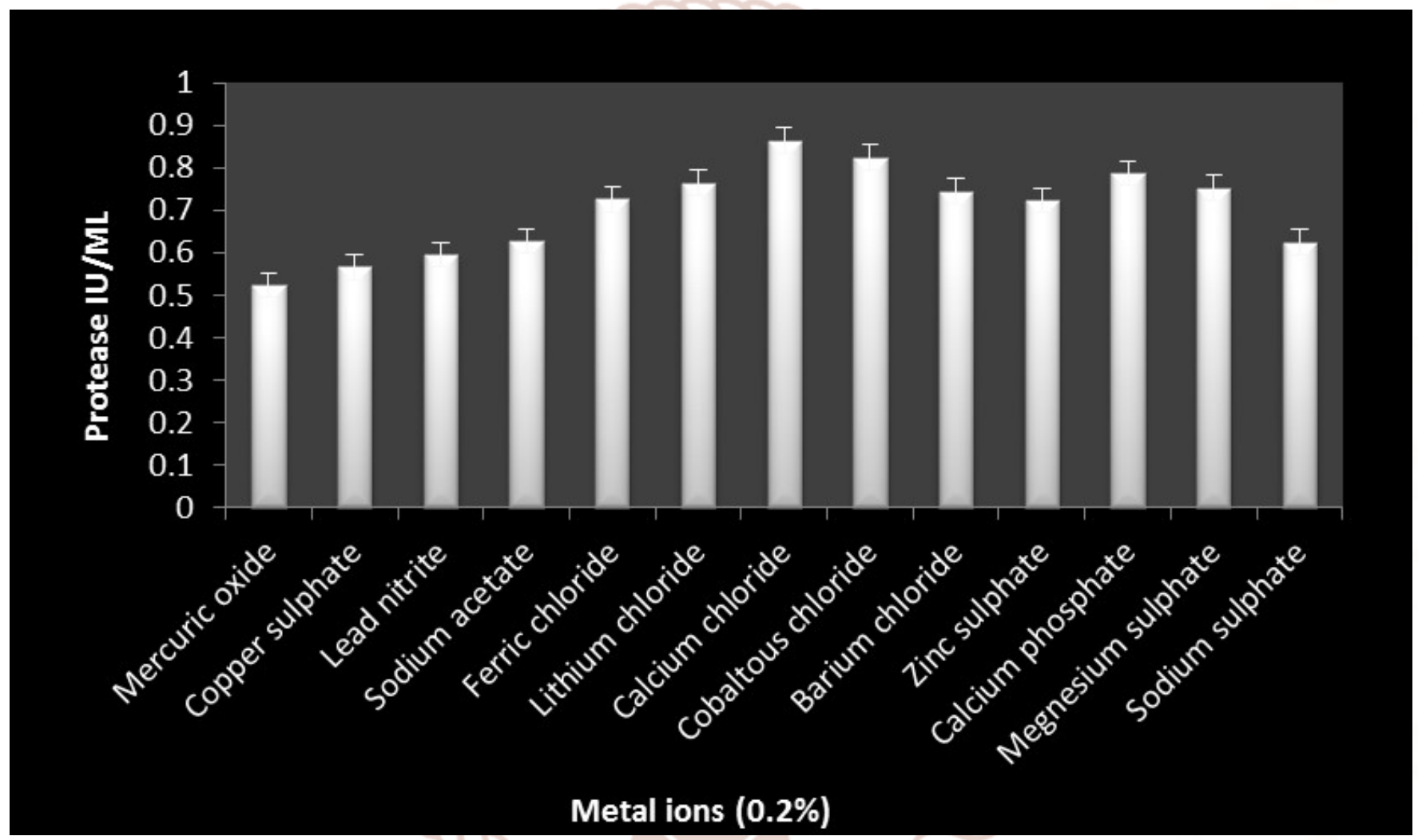

Fig. 7 Effect of metal ions on protease production

\section{Effect of $\mathrm{NaCl}$ concentration on protease production}

The effect of different $\mathrm{NaCl}$ concentration such as 1 , $1.5,2,2.5$ upto $5 \%$ for protease production after 72 hrs of incubation period at $40^{\circ} \mathrm{C}$ showed maximum amount of enzyme production in $2 . \% \mathrm{NaCl}$ (total activity $0.925 \pm 0.002 \mathrm{IU} / \mathrm{ml}$ ) and minimum amount of protease production in $5 \% \mathrm{NaCl}$ (total activity $0.333 \pm 0.003 \mathrm{IU} / \mathrm{ml}$ ) (fig. 8).

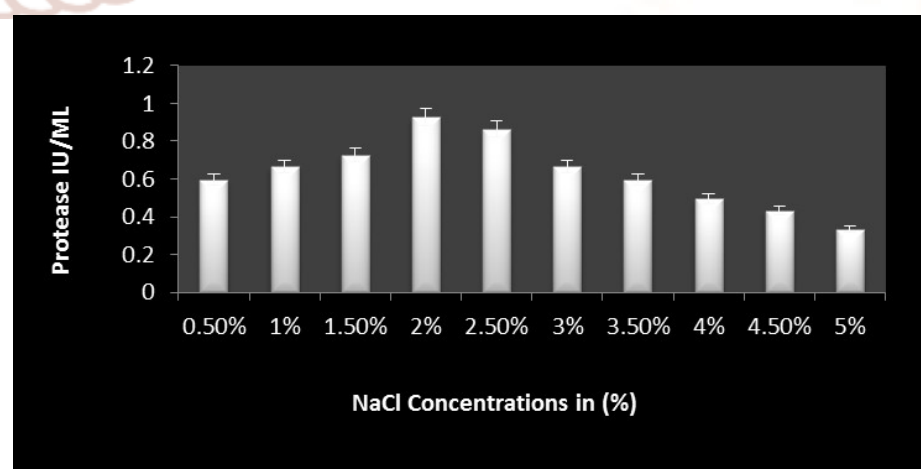

Fig.8 Effect of $\mathrm{NaCl}$ concentration on protease production 
Effect of surfactants protease production

Maximum amount of enzyme production in Tween 20 (total activity $0.926 \pm 0.002 \mathrm{IU} / \mathrm{ml}$ ) and minimum amount of protease production in SDS (total activity $0.335 \pm 0.004 \mathrm{IU} / \mathrm{ml}$ ) was observed (fig. 9).

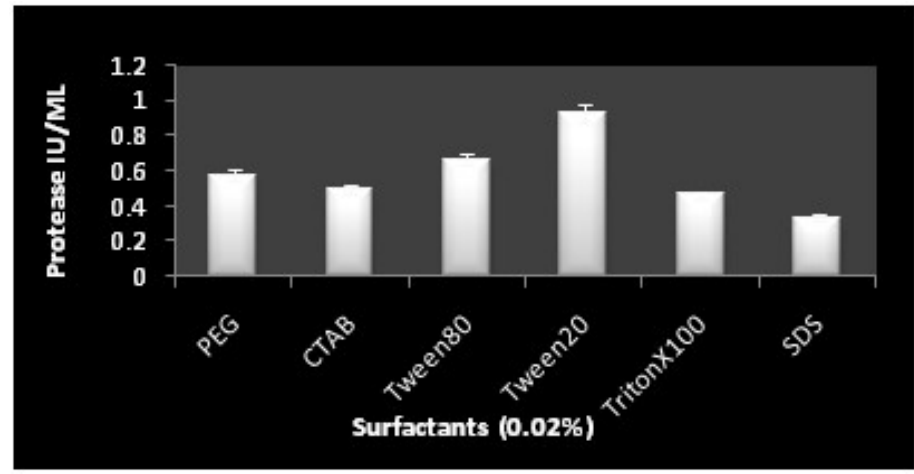

Fig. 9 Effect of surfactants protease production

Effect of inoculum concentration on protease production

Maximum amount of enzyme production in $4 \%$ inoculum (total activity $1.176 \pm 0.002 \mathrm{IU} / \mathrm{ml}$ ) and minimum amount of protease production in $0.5 \%$ inoculum (total activity $0.296 \pm 0.002 \mathrm{IU} / \mathrm{ml}$ ) was observed (fig. 10).

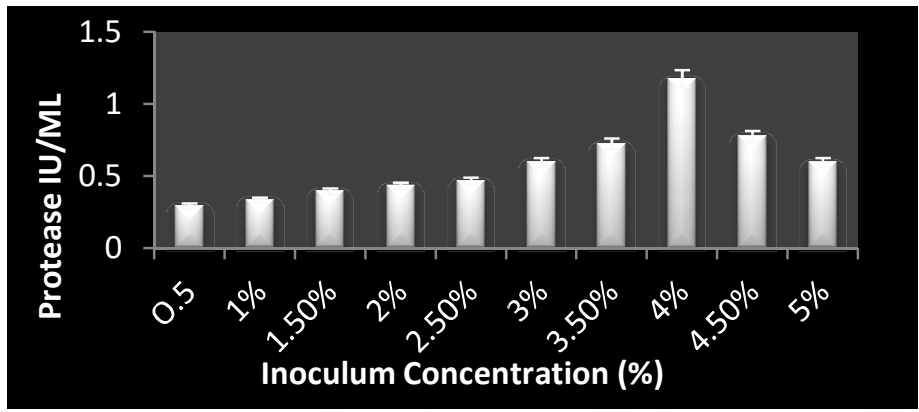

Fig. 10 Effect of inoculum concentration on protease production

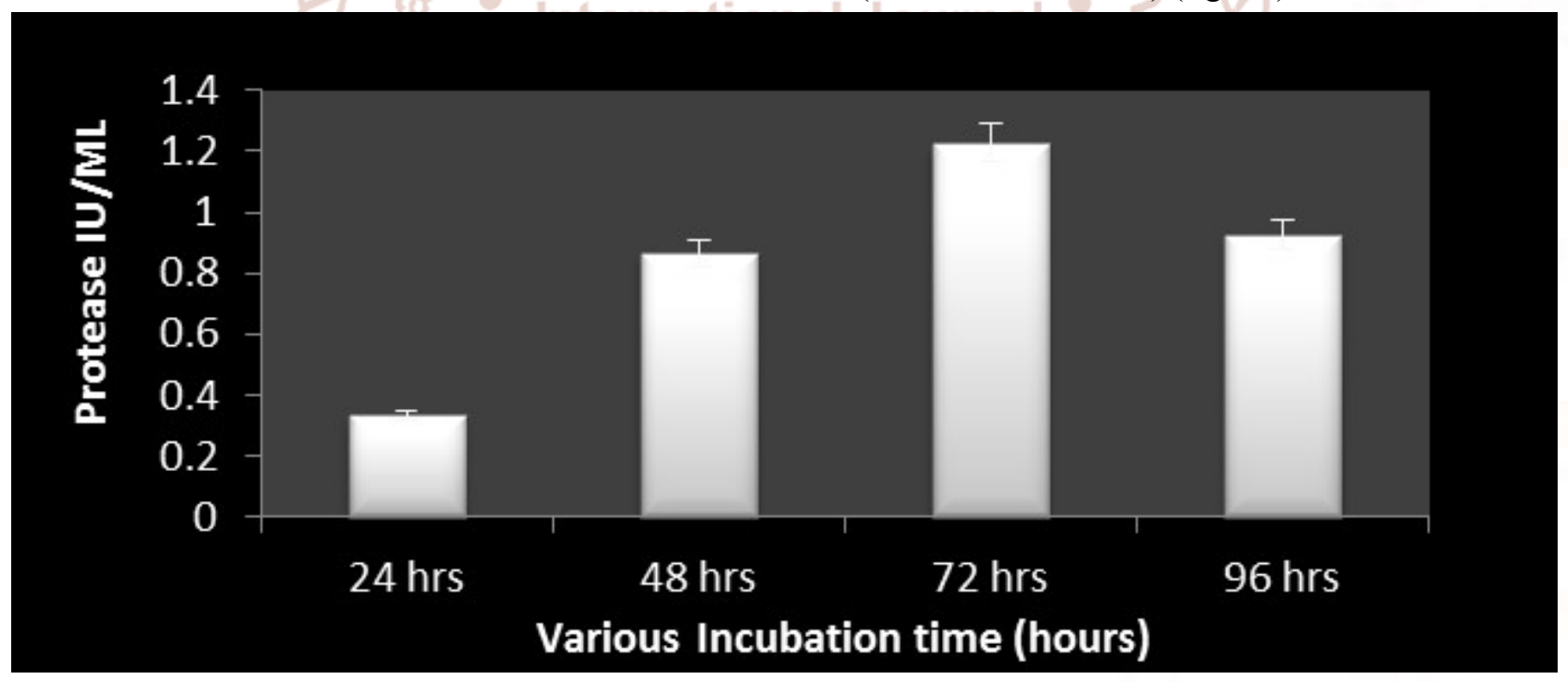

Fig. 11 Effect of incubation time on protease production

\section{Effect of aminoacids on protease production}

Maximum amount of enzyme production in cystein monohydrochloride (total activity $1.394 \pm 0.003 \mathrm{IU} / \mathrm{ml}$ ) and minimum amount of protease production in n-ornithine (total activity $0.334 \pm 0.003 \mathrm{IU} / \mathrm{ml}$ ) ( fig. 13) 


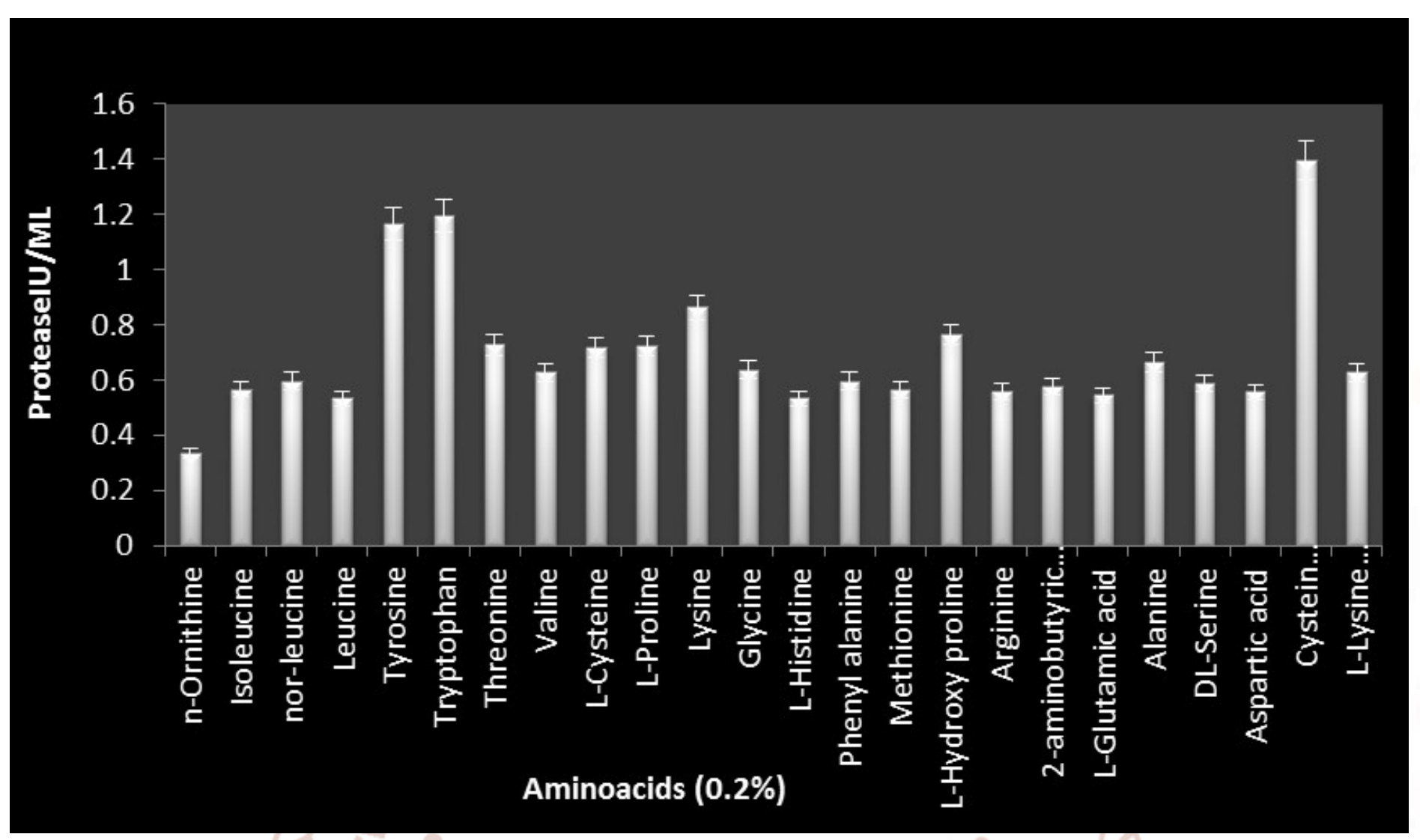

Fig. 13 Effect of aminoacids on protease production

\section{Effect of buffers on protease production}

Maximum amount of enzyme production in glycine $\mathrm{NaOH}$ (total activity $1.163 \pm 0.003 \mathrm{IU} / \mathrm{ml}$ ) and minimum amount of protease production in tris $\mathrm{Hcl}$ (total activity $0.826 \pm 0.002 \mathrm{IU} / \mathrm{ml}$ ) was observed in fig. 14.

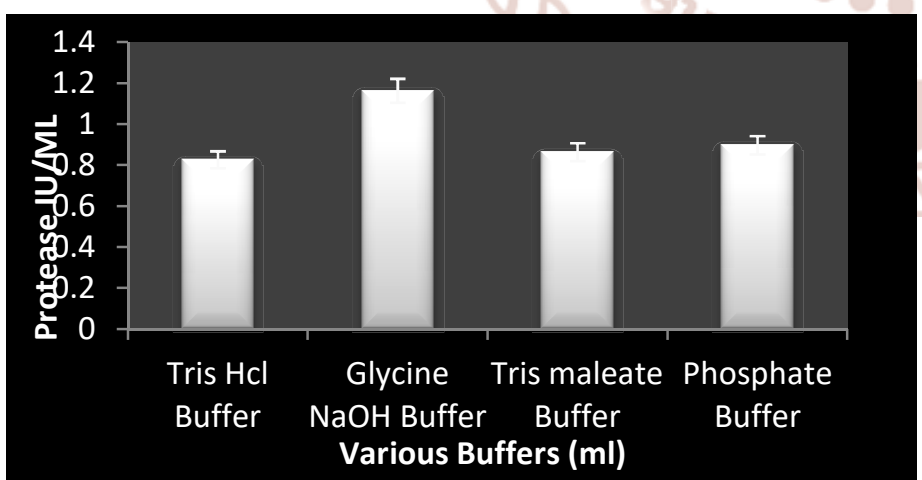

Fig. 14 Effect of buffers on protease production

\section{Effect of RPM}

The effect of various RPM condition was checked for protease production after incubation period at $40^{\circ} \mathrm{C}$ for $72 \mathrm{hrs}$ showed maximum amount of enzyme production in $100 \mathrm{RPM}$ (total activity $1.099 \pm 0.002$
$\mathrm{IU} / \mathrm{ml}$ ) and minimum amount of protease production in $50 \mathrm{RPM}$ (total activity $0.745 \pm 0.002 \mathrm{IU} / \mathrm{ml}$ ) ( fig. 16)

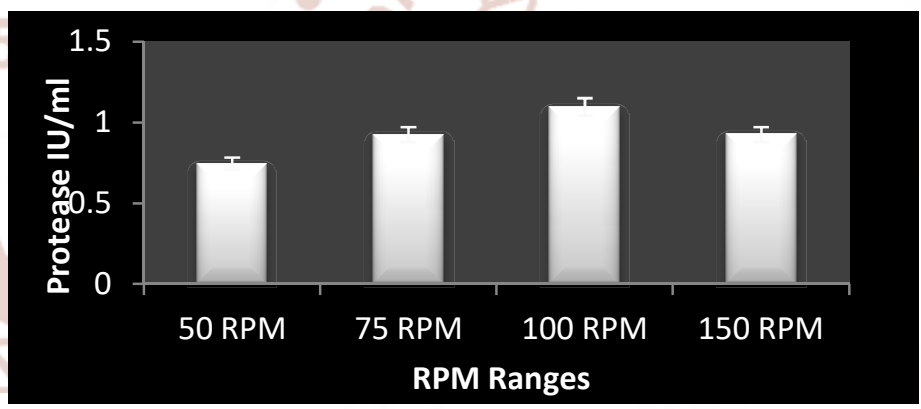

Fig. 16 Effect of RPM

\section{Effect of static and shaking condition}

The effect of static and shaking condition of for protease production after incubation period at $40^{\circ} \mathrm{C}$ for $72 \mathrm{hrs}$ showed maximum amount of enzyme production in shaking condition (total activity 1.427 $\pm 0.002 \mathrm{IU} / \mathrm{ml}$ ) and minimum amount of protease production in static condition (total activity $0.435 \pm$ $0.002 \mathrm{IU} / \mathrm{ml}$ ( fig. 12). 


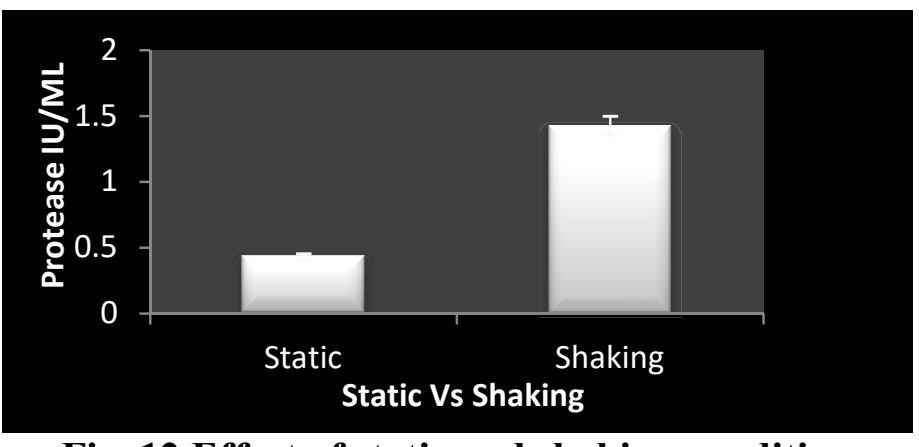

Fig. 12 Effect of static and shaking condition

\section{HPLC analysis for purified enzyme}

The purified enzyme of Oceanobacillus iheyensis were subjected to the analysis of HPLC chromatogram. The highest peak value of Oceanobacillus iheyensis in methanol extract i.e $2.143(\mathrm{mV})$ and lowest peak value was $2.707(\mathrm{mV})$. The results for HPLC of purified enzyme were shown in table:

Table: HPLC analysis of Oceanobacillus iheyensis KB7 purified enzyme.

\begin{tabular}{|l|l|l|l|l|}
\hline S.No & $\begin{array}{l}\text { Retention } \\
\text { time (min) }\end{array}$ & $\begin{array}{l}\text { Area } \\
(\%)\end{array}$ & $\begin{array}{l}\text { Height } \\
(\%)\end{array}$ & WO5(min) \\
\hline 1 & 2.143 & 33.1 & 70.6 & 0.11 \\
\hline 2 & 2.707 & 19.0 & 16.2 & 0.49 \\
\hline 3 & 2.870 & 47.8 & 13.2 & 1.03 \\
\hline
\end{tabular}

FIG: HPLC chromatogram for Oceanobacillus iheyensis $K B 7$

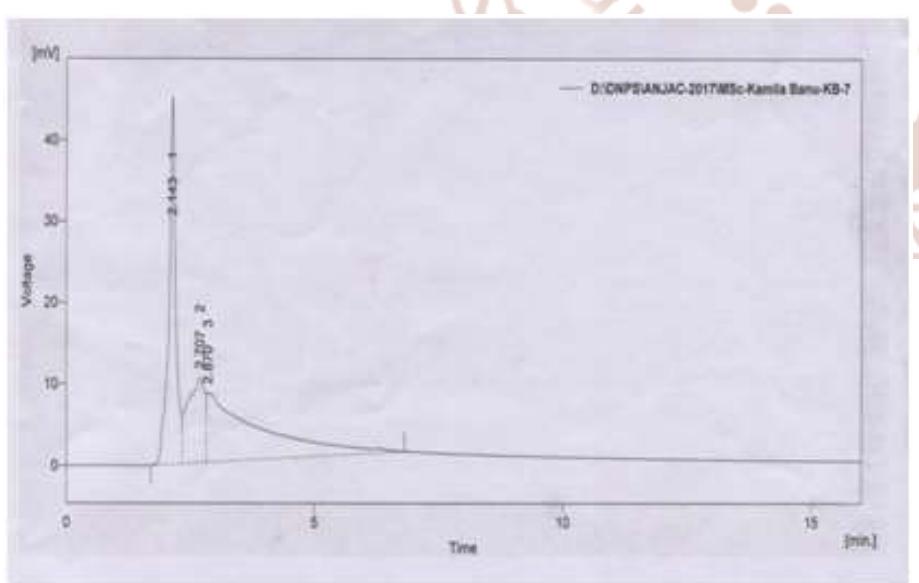

FIG: HPLC chromatogram for Oceanobacillus iheyensis $K B 7$

\section{DISCUSSION}

Bacterial strains were isolated on alkaline agar medium from various soil fields and identified on the basis of morphological cultural and biochemical characteristics (Cheesbrough, 2000). In the present study, the proteolytic activity for Oceanobacillus iheyensis was detected in casein agar medium with the zone of clearance $38 \mathrm{~mm}$. Likewise Bacillus subtilis isolated were then characterized for protease production using casein agar. Bacillus subtilis was found to produce protease on basis of clear zone around the bacterial colonies on $1 \%$ casein agar plates at $37^{\circ} \mathrm{C}$ after $24 \mathrm{hrs}$. The clear zones were due to hydrolysis of different substrates (Lin, 1996).

In the present study the $\mathrm{pH}$ of the medium seemed to be one of the important factors for the growth of the organisms. It was found that the maximum production was at $\mathrm{pH} \quad 8.0(1.455 \pm 0.003 \mathrm{IU} / \mathrm{ml})$ and the minimum activity was at $\mathrm{pH} 2(0.628 \pm 0.003 \mathrm{IU} / \mathrm{ml})$. Maximum enzyme production was obtained at $\mathrm{pH}$ range from 8.0-9.0 whereas Kumar et al., (2012) isolated two strains namely Bacillus species strain $\mathrm{S}_{4}$ and Pseudomonas species strains $\mathrm{S}_{22}$ and reported that protease production was maximum at $\mathrm{pH} 7$ and $\mathrm{pH} 9$ for respectively.

Temperature has profound influence on production of protease by microorganisms. Yossan et al., (2006) reported the optimum temperature of $50^{\circ} \mathrm{C}$ for Bacillus megaterium protease which retained the activity at $30-400^{\circ} \mathrm{C}$ with resulting relative activity of higher than $80 \%$. In the present study effect of temperature on protease production was maximum $(1.325 \pm 0.003 \mathrm{IU} / \mathrm{ml})$ at $40^{\circ} \mathrm{C}$ and minimum $(0.362 \pm$ $0.0144 \mathrm{IU} / \mathrm{ml}$ ) protease production recorded at $10^{\circ} \mathrm{C}$.

Carbon source is a primary energy source, which have important role in the improvement of growth of the organisms. In the present study, the experiments on the effect of various carbon sources on protease production showed that lactose maximize protease production was reported by several workers who used different sugars such as lactose, maltose, sucrose and fructose (Malathi and Chakraborthy, 1991). The results on the study of assimilation of carbon sources by $P$. aeruginosa showed that maximum growth was in sucrose for the parent strain whereas, for the mutant strain in presence of lactose and glucose (Mabrouck et al., 1999). The maximum $(1.163 \pm 0.003 \mathrm{IU} / \mathrm{ml})$ protease production was recorded in lactose supplemented medium. Minimum protease production was recorded in sucrose $(0.596 \pm 0.003 \mathrm{IU} / \mathrm{ml})$ added medium.

(Kumar and Tagaki, 1999) reported that effect of specific nitrogen supplement on protease production 
differs from organism to organism. In present study the effect of various organic nitrogen sources was tested. The result showed that peptone gave their maximum influence on protease production. The maximum $(0.895 \pm 0.002 \mathrm{IU} / \mathrm{ml})$ amount of enzyme production was observed in peptone supplemented medium.

Tolerance of enzyme upto $5 \mathrm{M}$ of $\mathrm{NaCl}$ over $24 \mathrm{hrs}$ without losing original activity was reported by Jana et al.,(1997). Considering the importance of Sodium chloride, the present study was conducted and the result showed that the test organism can utilize the salt content within the range between $0.5-5 \%$ for maximizing the protease production and it was remarkably high in $2 \%$ sodium chloride $(0.925 \pm$ 0.002) supplemented medium.

Joo and Chang, (2005) reported that the protease production from Bacillus clausii and Bacillus spp. which retained their activity with different surfactants such as Triton X 100, Tween-20 and SDS.-The protease production was high $(0.926 \pm 0.002 \mathrm{IU} / \mathrm{ml})$ at Tween-20 supplemented medium. Enzyme production was markedly reduced $(0.335 \pm 0.004 \mathrm{IU} / \mathrm{ml})$ at SDS supplemented medium.

Metal ions are often required by bacterium for its growth and physiological activities. In the present study the maximum $(0.864 \pm 0.003 \mathrm{IU} / \mathrm{ml})$ protease production was recorded in $\mathrm{CaCl}_{2}$ supplemented medium. Minimum protease production was recorded in $\mathrm{HgO}_{2}(0.524 \pm 0.003 \mathrm{IU} / \mathrm{ml})$ added medium. Najafi et al.,(2005) reported that protease production by Aspergillus $s p$. showed maximum activity with metal ions as $\mathrm{Ca}^{2+}, \mathrm{Mg}^{2+}$ and inhibited by EDTA. Folasade et al., (2004) reported that the supplementation of the culture medium with a solution of metal ions improved substantially the growth of Bacillus $s p$ and also the enzyme production. Rahman et al., (2006) reported protease production by $P$. aeruginosa was increased with metal ions such as $\mathrm{Ca}^{2+}, \mathrm{Mg}^{2+}$ and $\mathrm{K}^{+}$.

The incubation period of $30 \mathrm{hrs}$ gave the maximum production for the Bacillus subtilis PE-II cultures in protease production broth Johnvesly et al., (2007). The protease production was high $(1.226 \pm 0.002$ $\mathrm{IU} / \mathrm{ml})$ at $72 \mathrm{hrs}$ of incubation. The nature of inoculums as well as its size may affect the microbial process to evaluate the effect of inoculums level on alkaline protease production. Protease enzyme production was high at $4 \%$ of inoculum size while using cotton seed as a fermenting medium. The $\operatorname{maximum}(1.176 \pm 0.002 \mathrm{IU} / \mathrm{ml})$ amount of enzyme production was observed in $4 \%$ inoculums added medium.

Buffers are often required by bacterium for its growth and physiological activities. In the present study the maximum $(1.163 \pm 0.003 \mathrm{IU} / \mathrm{ml})$ protease production was recorded in Glycine - $\mathrm{NaOH}$ supplemented medium. Minimum protease production was recorded in Tris $\mathrm{Hcl}$ buffer $(0.826 \pm 0.002 \mathrm{IU} / \mathrm{ml})$ added medium. Najafi et al., (2005) reported that protease production by Aspergillus sp. showed maximum activity with buffers as sodium acetate buffer. Folasade et al., (2004) reported that the supplementation of the culture medium with a solution of buffer improved substantially the growth of Bacillus $s p$ and also the enzyme production. Rahman et al., (2006) reported protease production by $P$. aeruginosa was increased with buffer in alkaline condition.

The RPM condition of 30 hrs gave the maximum production for the Bacillus subtilis PE-II cultures in protease production broth (Kumar and Tagaki, 1999). Similarly in the present study shaking condition of protease production was high $(1.095 \pm 0.003 \mathrm{IU} / \mathrm{ml})$ at $100 \mathrm{rpm}, 72 \mathrm{hrs}$ of incubation. Enzyme production was markedly reduced in $50 \mathrm{rpm}(0.744 \pm 0.002$ $\mathrm{IU} / \mathrm{ml}$ ) at $72 \mathrm{hrs}$ of incubation. Atalo et al., (1993) observed maximum production at $48 \mathrm{hrs}$.

The static and shaking condition of $30 \mathrm{hrs}$ gave the maximum production for the Bacillus subtilis PE-II cultures in protease production broth Johnvesly et al., (2007). In shaking condition of protease production was high $(1.427 \pm 0.002 \mathrm{IU} / \mathrm{ml})$ at $72 \mathrm{hrs}$ of incubation. Enzyme production was markedly reduced in static condition $(0.432 \pm 0.003 \mathrm{IU} / \mathrm{ml})$ at $72 \mathrm{hrs}$ of incubation. Atalo et al., (1993) observed maximum production at $48 \mathrm{hrs}$.

In the present study, first step of purification of the enzymes was carried out by precipitation of protein from the cell free dialysate with carbinol at the saturation level of $60 \%$. This resulted in 3 folds of purification with yields of 91.45 and specific activity of $(1.673 \pm 0.002 \mathrm{IU} / \mathrm{ml})$. However, at $60 \%$ saturation most of the protease enzymes were precipitate out. The salt content was removed by performing the ionexchange chromatography.

The HPLC analysis of Oceanobacillus iheyensis KB7 was result the peak formation they conclude the information about the amino acids and alkyl groups in 
the extract. Similar studies have been done that the fractions purified by reversed phase HPLC and yielded six purified compounds, namely acacetin $8-C$ $(\alpha-1$ - rhamnopyranosyl - (152) - $\beta$ - dglucopyranoside), 2 "- $O$ - $\alpha$ rhamnopyranosyl - vitexin, quercetin and kaempferol was observed. In this current study, 3 peaks were obtained from the HPLC analysis of the Oceanobacillus iheyensis KB7 purified enzyme extracts.

\section{REFERENCE:}

1. Annamalai, N., Rajeshwari, MV., Sahu, SK., Balasubramanian, T. (2014). Purification and characterization of solvent stable, alkaline protease from Bacillus firmus CAS7 by microbial conversion of marine wastes and molecular mechanism underlying solvent stability. Process. Biochem., 49: 1012-1019.

2. Anshu Gupta \& Khare, S.K. (2007). Enhanced production and characterization of a solvent stable protease from solvent tolerant Pseudomonas aeruginosa. Enzyme and Microbial Technology., 42: 11-16.

3. Atalo, K. and Gashe, B.A. (1993). Protease production by a thermophilic Bacillus spp (P001A) which degrades various kinds of fibrous proteins. Biotechnol. Lett., 11: 1151-1156.

4. Beg, Q.K. and Gupta, R. (2003). Purification and Characterization of an oxidation stable thioldependent serine alkaline protease from Bacillus majavensis. Enz. Microbiol. Techn., 32: 294-304.

5. Cheesbrough, M. (2000). Bacterial pathogens. In: District laboratory practice in tropical countries. ELBS London., 2: 157-234.

6. Choudhry, A.E., Mandichak, T.L., Broskey, J.P., Egolf, R.W., Kinsland, C., and Begly, T.P. (2003). Inhibitors of pantothenate kinase: novel antibiotics for Staphylococcal infections. Antimicrob. Agents. Chemother., 47: 2051-2055.

7. Das, G. and Prasad, M.P. (2010). Isolation, purification \& mass production of protease enzyme from Bacillus subtilis. International Research Journals of Microbiology., 1(2): 026031.

8. Devlin, T.M. (2002). Text Book of Biochemistry with Clinical Correlations. Wiley \& Sons, NY: 5(ed). dissolved oxygen tension and $\mathrm{pH}$ on the production of extracellular protease from a new isolate of Bacillus subtilis $\mathrm{K} 2$, for use in leather processing. J Chem Technol Biotechnol, 74 (1): 58.

9. EI-Enshasy, H., Abuoul-Enein, A., Helmy, S., and EI Azaly, Y. (2008). Optimization of the industrial production of alkaline protease by Bacillus licheniformis in different production scales. Australian Journal of Basic and Applied Sciences, 2(3): 583-593.

10. Ferid abidi and Ferid Limam. (2008). Production of alkaline proteases by Botrytis cinerea using economic raw materials: Assay as biodetergent. Process. Biochemistry. 43: 1202-1208.

11. flavus and its characterization. Afr. J. Biotechnol., 10(43): $8630-8640$

12. Folasade, M.O. and Ajele, J.O. (2004). Production dynamics of extra cellular protease from Bacillus sp. Afr. J. Biotechnol., 4: 776-779.

13. Frikha, F.B., Sellami, A., Fakhfakh, N., Haddar, A., Manni, L. and Nasari, M. (2005). Production and purification of a calcium-dependent protease from Bacillus cereus BG1. J. Ind. Microbiol. Biotechnol., 32: 186-194.

14. Gehan, M., Abou-Elela, Hassan, A.H., and Ibrahim Sahar, W. (2011). Alkaline protease production by alkaliphilic marine bacteria isolated from Marsa-Matrouh (Egypt) with special emphasis on Bacillus cereus purified protease. African Journal of Biotechnology, 22 : 4631-4642.

15. Ikram-ul-haq. (2003). Production of alkaline protease by Bacillus subtilis and its application as a depilating agent in leather processing. Pak. J. Bot., 40(4): 1673-1679.

16. Jana, M., Chattopadhayay, D.J. and Pati, B.R. (1997). Thermo stable, high salt tolerant amylase from Bacillus megaterium VUMB-109. Acta Microbiol. Immunol. Hug., 45(2): 281-289.

17. Jaswal, R.K., Kocher, G.S. and Virk, M.S. (2008). Production of alkaline protease by Bacillus circulans using agricultural residues: A statistical approach. Indian journal of Biotechnology., 7: 356-360.

18. Johnsen, A., and Flink, J.M. (1986). Influence of alginate properties and gel reinforcement on fermentation characteristics of immobilized yeast cells. Enzy. Microb. Technol., 8: 737-748. 
19. Johnvesly, S. and Naik, G.R. (2007). Studies on production of thermostable alkaline protease from thermophilic and alkalophilic Bacillus spp. Jb-99 in a chemically defined medium. Process. Biochem., 37: 39-144.

20. Joo, H.S. and Chang, C.S. (2005). Production of protease from a new alkalophilic Bacillus spp. J. App. Microbiol., 1: 309-312.

21. Kalpana Devi, M., Rasheedha Banu, A., Gnanaprabhal G.R., Pradeep, B.V. and Palaniswamy, M. (2008). Purification, characterization of alkaline protease enzyme from native isolate Aspergillus niger and its compatibility with commercial detergents. Indian journal of Science and Technology., 1: 1-6.

22. Kanekar, P.P., Nilegarokar, S., Sarnaik, S.S. and Kelkar, A.S. (2002). Optimization of protease activity on alkalophilic bacteria, isolated from an alkaline lake in India. Biores. Technol., 85: 87-93.

23. Katsaros, G.I., Katapodis, P., and Taoukis, P. S. (2009). Modeling the effect of temperature and high hydrostatic pressure on the proteolytic activity of kiwi fruit juice. Journal Of Food Engineering., 94: 40-45

24. Kumar, A., Sachdev, A., Balasubramanyam, S.D., Saxena, A.K. and Lata, A. (2002). Optimization of conditions for production of neutral and alkaline proteas from species of Bacillus and Pseudomonas. Ind. J. Microbiol., 42: 233-236.

25. Kumar, C.G. and Takagi, H. (1999). Microbial alkaline proteases : from a bio industrial view point. Biotechnol. Advances., 17: 561-569.

26. Kumar, C.G., and Takagi, H. (1999). Microbial alkaline proteases: from a bioindustrial viewpoint. Biotechnology. advances., 17(7): 561-594.

27. Kumar, C.G., Tiwari, M.P. and Jany, K.D. (1998). Novel alkaline serine protease from alkalophilic Bacillus spp. Purification and characterization. Process Biochem., 34: 441-449.

28. Kumar, P.P.K., Mathivana, V., Karunakaran, M., Renganathan, S., and Sreenivasan, R.S. (2008). Studies on the effects of $\mathrm{PH}$ and incubation period on protease production by Bacillus sp.using ground nut cake and wheat bran. Indian. J. Science. Technology., 1(4): 1-4.

29. Kumar, S., and Khare, S.K. (2012). Purification and characterization of maltooligosaccharideforming a-amylase from moderately halophilic Marinobacter sp. EMB8. Bioresource Technology., 116: 247-251.

30. Kunitz, M. (1947). Crystalline soybean trypsin inhibitor. II. General properties. J. Gen. Physiol., 30: 291-310.

31. Lin, Y., (1996). Characteristics and action pattern of alkaline protease produced from Bacilis spp cw-1121, Korean. Biochem., J., 24: 537-542.

32. Lowery, O.H., Rosebrough, N.J., Farr, A.L., Randall, R.J., (1951). Protein measurement with the Folin phenol reagent. J. Biol. Chem., 93 (1): 265-275.

33. Mabrouck, S.S., Hashem, A.M., Eshayeb, N.M.A., Ismail, A.M.S. and Fattah, A.F. (1999). Optimization of alkaline protease productivity by Bacillus licheniformis ATCC 21415. Biores. Technol., 69: 155-159.

34. Malathi, S. and Chakaraborthy, R. (1991). Production of alkaline protease by a new Aspergillus flavus isolate under solid substrate fermentation conditions for use as a depilation agent. Appl. Environ. Microbiol., 57: 712-716.

35. Maruthiah, T., Esakkiraj, P., Immanuel, G., Palavesam, A. (2014). Alkaline serine protease from B Bacillus fluxus AP-CMST-RS2P: purification and characterization, Curr. Biotechnol., 3: 2211-5501.

36. Maruthiah, T., Immanuel, G., Palavesam, A. (2015). Purification and characterization of halophilic organic Solvent tolerant protease from marine Bacillus sp. APCMST-RS7 and its antioxidant potentials. Proc. Natl. Acad. Sci. India. Sect. B. Biol., pp. 400-0603.

37. Najafi, M.f. and Deobagkar, D. (2005). Potential application of protease isolated from Pseudomonas aeruginosa. Eur. J. Biotechnol., 8: 197-203.

38. Ogino, H., Watanabe, F., Yammada, M., Nakagawa, S., Hirose, S.T., Noguchi, A., Yasuda, M. and Ishikawa, H. (1999). Purification and characterization of organic solvent-stable protease from organic solvent-tolerant Pseudomonas aeruginosa PSTO1. J. Biol. Sci. Bioeng., 87: 6168.

39. Rahman, R.N.Z.A., Razak, C.N., Ampon, K., Basri, M., Yunus, W.M.Z.W. and Salleh, A.B. (2006). Purification and characterization of a heat stable alkaline proteases from Bacillus 
International Journal of Trend in Scientific Research and Development (IJTSRD) ISSN: 2456-6470

stearothermophilus $\quad \mathrm{F}_{1}$. Appl. Microbiol. Biotechnol. 40: 822-827.

40. Ramakrishna, S.V. and Prakasham, R.S. (1999). Microbial fermentation with immobilized cells. Curr. Sci., 77: 87-100.

41. Sabu, A. (2003). Sources, properties and applications of microbial therapeutic enzymes. Indian Journal Of Biotechnology., 2: 7.

42. Sankaralingam, S., Kuberan, T., and Reddy, S. (2012). Production of protease from Bacillus licheniformis isolated from the gut of shrimp. $J$. Biosci. Res., 3(3): 136-141.

43. Saeki, K., Ozaki, K., Kobayashi, T., and Ito, S. (2007). Detergent alkaline proteases: enzymatic properties, genes, and crystal structures. J Biosci Bioeng., 103(6): 501-508.

44. Sexton, M.M., Jones, A.L., Chaowagul, W. and Woods, D.E. (1994). Purification and characterization of a protease from Pseudomonas pseudomallei. Can. J. Microbiol. 40: 903-910.

45. Shankar, S., More, S.V., and Laxman R.S. (2010). Recovery of silver from waste $x$-ray film by alkaline protease from Conidiobolus coronatus. KUSET 6(1): 60-69.

46. Shankar, S., More, S.V., and Seeta Laxman, R. (2007). Recovery of silver from waste x-ray film by alkaline protease from Conidiobolus Coronatus. Indian journal of Biotechnology, 6: 60-69.

47. Sharmin, S., Hossain, M.D.T., Seghalkiran, G.S. and Natarajaseenivasan, K. (2007). Optimization of extra cellular thermo tolerant alkaline protease produced by marine Rosobacter spp (MMD040). Bioprocess. Biogyst. Eng., 2: 23-28.

48. Sinha, R., and Khare, S. K. (2013). Characterization of detergent compatible protease of a halophilicBacillus sp. EMB9: Differential role of metal ions in stability and activity. Bioresource technology, 145: 357-361.

49. Sinsuwan, S., Rodtong, S., and Yongsawatdigul, J. (2009). Purification and characterization of a saltactivated and organic solvent-stable heterotrimer proteinase from Virgibacillus sp.SK33 isolated from Thai fish sauce. Journal of agricultural and food chemistry., 58(1): 248-256.

50. Stoner, M.R., Dale, D.A., Gualfetti, P.T., Becker, T., Manning, M.C. and Carpenter, J.F. (2004).
Protease autolysis in heavy-duty liquid detergent formulation: effect of thermodynamic stabilizers and protease inhibitors. Enz. Microbiol. Technol., 34: 114-125.

51. Vaishali Choudhary. (2013). Recovery of Silver from used X- ray films by Aspergillus versicolor protease. Journal of Academia and Industrial Research., 2(1): 39-41.

52. Vijayaraghavan, P., Vijayan, A., Arun, A., Jenisha, J., and Vincent, S. G. P. (2012). Cow dung: a potential biomass substrate for the production of detergent-stable dehairing protease by alkaliphilic Bacillus subtilis strain. VV.SpringerPlus., 1(1): 76.

53. Vishalakshi, N., Lingappa, K., Amena, S., Prabhakr, M. and Dayanand, A. (2009). Production of alkaline protease from Streptomyces gulbargensis and its application in removal of blood stains. Indian Journal of Biotechnology., 8: 280-285.

54. Yossan, Q., Peng, Y., Li, X., Wang, H. and Zhang, Y. (2006). Purification and characterization of an extra cellular alkaline serine protease with dehairing function from Bacillus pumilus. Curr. Microbiol., 46: 169-173. 